\title{
Marketing capabilities: do they matter in INVs?
}

\section{Andreu Blesa*, María Ripollés and Diego Monferrer}

\author{
Universitat Jaume I de Castellón, \\ Facultad de Ciencias Jurídicas y Económicas, \\ Dpto. Administración de Empresas y Marketing, \\ Campus del Riu Sec, s/n, 12071 Castellón, Spain \\ E-mail: blesa@emp.uji.es \\ E-mail: mripolle@emp.uji.es \\ E-mail: dmonferr@emp.uji.es \\ *Corresponding author
}

\begin{abstract}
This paper examines the influence that marketing capabilities developed in international new ventures can have on their international performance and international geographical diversification. Rapid entry in foreign markets is also highlighted as a factor contributing to the development of marketing capabilities in international new ventures. The central concept advanced in the paper is that international new ventures generate competitive advantages associated with early internationalisation that derive from their influence on the development of marketing capabilities in these firms. The study's conclusions provide new keys for the literature on entrepreneurship and marketing, and will contribute to improve our understanding of how new international ventures behave.
\end{abstract}

Keywords: entrepreneurship; marketing capabilities; marketing strategy; rapid international entry; economic performance; international geographical diversification.

Reference to this paper should be made as follows: Blesa, A., Ripollés, M. and Monferrer, D. (2010) 'Marketing capabilities: do they matter in INVs?', World Review of Entrepreneurship, Management and Sustainable Development, Vol. 6, Nos. 1/2, pp.71-99.

Biographical notes: Andreu Blesa is an Associate Professor of Marketing in the Department of Business Administration and Marketing at Universitat Jaume I, Spain. His research interests include market orientation, distribution channels, relationship marketing and marketing/entrepreneurship interface. $\mathrm{He}$ has published articles in journals such as International Marketing Review, Annals of Tourism, Journal of Entrepreneurship, International Journal of Retail and Distribution Management, European Journal of Marketing, International Journal of Entrepreneurship and Innovation and Investigaciones Económicas, and has presented papers at several conferences such as the European Marketing Academy, Research in Entrepreneurship and Small Business and the European Conference on Entrepreneurship and Innovation.

María Ripollés is an Associate Professor of Management in the Department of Business Administration and Marketing at Universitat Jaume I, Spain. Her research interests include entrepreneurial orientation, firms' internationalisation processes, foreign entry modes and international entrepreneurship. She has published articles in journals such as International Marketing Review, Journal 
of Entrepreneurship, International Journal of Entrepreneurship and Innovation, Journal of International Entrepreneurship and Investigaciones Económicas, and has presented papers at several conferences such as the European International Business Academy Conference, the European Academy of Management Conference, the European Marketing Academy, Research in Entrepreneurship and Small Business and the European Conference on Entrepreneurship and Innovation.

Diego Monferrer is an Assistant Professor of Marketing in the Department of Business Administration and Marketing at Universitat Jaume I, Spain. His research interests include market orientation, business networks, international new ventures, international marketing and the marketing/entrepreneurship interface. He has published articles in journals such as Journal of International Entrepreneurship and Investigaciones Económicas, and has presented papers at several conferences such as the European Conference on Entrepreneurship and Innovation, Research in Entrepreneurship and Small Business, the European Marketing Academy Conference and the International Congress on Marketing Trends.

\section{Introduction}

The last 15 years have witnessed the emergence of new firms that do not follow the gradual internationalisation pattern generally predicted by gradualist approaches (Johanson and Vahlne, 1977). These firms are characterised by their rapid entry in international markets. Following Oviatt and McDougall (1994), in this paper we refer to these firms as international new ventures (INVs). These authors define an INV as 'a business organisation that, from inception, seeks to derive significant competitive advantage from the use of resources and the sale of outputs in multiple countries. The distinguishing feature of these start-ups is that their origins are international, as demonstrated by observable and significant commitments of resources (e.g., material, people, financing, time)' [Oviatt and McDougall, (1994), p.49].

The existence of INVs and their growing importance in globalised environments (OECD, 1997; Hessels and van Stel, 2009) has encouraged many researchers to study which aspects can influence the early internationalisation of these firms. This interest has secured academic recognition and legitimacy for a new research line known as 'international entrepreneurship' (Zahra and George, 2002). However, the factors that can influence the international success of INVs and the relationships between them (Oviatt and McDougall, 2005) are not yet fully understood. It is particularly noteworthy that, more than a decade after the publication of Oviatt and McDougall's seminal work in 1994, little research has been undertaken into the competitive consequences resulting from rapid internationalisation of INVs, although both Oviatt and McDougall (1994) and later Autio et al. (2000) indicate that a significant proportion of INVs' international success may be due to the competitive advantages that seem to stem from early internationalisation. Autio et al. (2000) refer to these advantages as the learning advantages of newness and suggest that they are related to the possible consequences of early international orientation in INVs. Following recent calls for research, we consider it necessary to extend the analysis of how INVs can develop learning advantages of newness and obtain superior performance levels than their competitors in international 
markets. This study will contribute significantly to furthering knowledge on how firms without resources and experience can be competitive in foreign markets. In this line, Zahra (2005) states that the concept of learning advantages of newness sheds light into the black hole that appears to exist in the literature regarding the factors that influence the competitiveness and international performance of INVs.

The paper develops a model of relationships that explains how rapid entry in foreign markets influences international performance in INVs. Following the suggestion of Autio et al. (2000), we explore the possible influence that rapid entry in foreign markets can have on INVs' capabilities for managing the information and knowledge deriving from foreign markets. To this end, we adopt a marketing approach which links the firm's capability to manage market information and knowledge with its marketing capability (Day, 1994). While this perspective has not been at the forefront of INV research, we believe it has a great deal to contribute if we consider that the international success of INVs lies in their ability to manage the information and knowledge coming from the international market (Oviatt and McDougall, 2005). The specific issues we aim to investigate are therefore: does rapid entry into foreign markets contribute to developing marketing capabilities in INVs? What are the consequences of developing marketing capabilities in INVs? Do marketing capabilities translate into an international marketing strategy that allows INVs to improve their international economic performance, as occurs in other types of firms?

In addition, given that the capability to manage market information and knowledge can influence firms' international geographical diversification (Johanson and Vahlne, 1977), in this paper we also analyse whether the development of marketing capabilities can influence the international geographical diversification of INVs. In their definition of INVs, Oviatt and McDougall (1994) suggest that these firms can obtain significant benefits from their international activity in different markets. INVs can obtain economic benefits by exploiting a range of assets through a large number of international markets (Kuivalainen et al., 2007). International activity in diverse locations can help INVs to obtain advantages based on location (Kogut, 1985), access critical resources (Deeds and Hill, 1998) and develop new knowledge and capabilities that increase their international competitiveness (Shan and Song, 1997; Zahra et al., 2000). On the other hand, the decision to enter and operate in new markets involves taking on the additional risk resulting from the lack of tacit and explicit knowledge about that market (Zaheer, 1995) and from the fact that INVs must adapt their offer to the specific needs of these markets, together with the coordination requirements that international activity demands (Cadogan et al., 2006). The possible benefits associated with international geographical diversification of INVs, together with the challenges inherent in operating simultaneously in different foreign markets, justify the study of the factors that shed light on the international geographical diversification of the markets in which INVs operate. This analysis is important in that it furthers understanding of the factors that explain how these firms are able to operate in different foreign markets at the same time and to discover how they behave globally, and how this behaviour differs from other international behaviours (Gabrielsson et al., 2008).

The analysis of these questions contributes, firstly, to exploring how rapid international entry helps new firms to develop marketing capabilities. In this vein, the present study questions one of the hypotheses put forward by gradualist models of internationalisation, in which firm experience and physical presence in international 
markets play a fundamental role in explaining how firms develop their marketing capabilities (Bilkey and Tesar, 1977; Johanson and Vahlne, 1977, 1990; Cavusgil, 1980). The present paper therefore enhances prior international research by considering a new source for the generation of marketing capabilities in international markets.

Secondly, it has generally been assumed that the resources available to new firms are scarce, which makes it difficult to explain how these firms obtain superior competitive results in diverse international markets. Likewise, previous research has associated INVs with certain specific capabilities, whether technical, relational or adaptational (Fernhaber and McDougall, 2005). However, with the exception of work by Weerawardena et al. (2007), few authors have analysed the influence of marketing capabilities on INVs' performance. The present study therefore contributes to the development of research in this field, by providing an alternative explanation for superior performance based on the influence of rapid international entry on marketing capabilities.

Thirdly, by considering rapid international entry as an independent variable that can help to explain the performance of INVs, we complement previous research that has focused on determining the factors that can positively influence the speed with which some new firms internationalise (Oviatt and McDougall, 2005; Rialp et al., 2005).

Fourthly, the global nature of the products or services offered by INVs and the factors that lie behind the globalisation of the economy may 'a priori' predispose INVs towards global behaviour (Hessels and van Stel, 2009). However, these factors are not sufficient to explain the number of markets in which INVs are present. This study extends previous international entrepreneurship research by analysing how the development of marketing capabilities may affect the international geographical diversification of INVs.

Finally, by centring on international economic performance, we use a multidimensional measure of the concept, thus complementing the existing literature that has considered increase in international sales as the main variable to represent international performance in INVs (Autio et al., 2000, 2005; Autio, 2005; Fernhaber and McDougall, 2005; Zheng and Kavul, 2005).

Following this introduction, the paper establishes the theoretical grounding for the proposed model. The relationships configuring the model are then presented. This is followed by an outline of the methodology used in the sample selection, and the choice of measurement scales. The results obtained by testing the model with a sample of INVs are then reported. Finally, we discuss the results of the study, together with its limitations, implications and possible future research lines.

\section{The importance of marketing capabilities in INVs}

Initial INV research was limited to confirming the existence of a new type of firm that operates internationally almost from inception, and at the same time highlighted early international entry as a characteristic factor of these firms. These early studies also showed how arguments put forward by some of the more traditional and recognised schools of research into business internationalisation such as the Swedish Uppsala model (Johanson and Vahlne, 1977, 1990), export development models related to innovation (Bilkey and Tesar, 1977; Cavusgil, 1980; Reid, 1981), or those proposed by network theory, apparently failed to explain INVs' behaviour (McDougall et al., 1994; Oviatt and McDougall, 1994). INVs are international from inception, and as such do not have 
sufficient time to learn and acquire knowledge from experience, as argued from the gradualist model perspective. Furthermore, the internationalisation of these firms corresponds to a proactive rather than a reactive attitude, as generally understood in these schools (Zahra and George, 2002; Coviello and Jones, 2004; Rialp et al., 2005; Zahra, 2005; Aspelund et al., 2007).

The paper presented by McGill in 1998 marked the consolidation of the study of INVs as a research line identified as 'international entrepreneurship (IE)' (Dana and Wright, 2004). The main focus of studies within this research line is the analysis of factors that can explain early international entry by new firms. Some of these studies highlight the role of industry characteristics or environmental factors (Bloodgood et al., 1995; Johnson, 2004). Other authors discuss the influence of various internal capabilities necessary for early internationalisation (Johnson, 2004); for example, certain entrepreneurs have been shown to possess a set of knowledge, skills and relationships that allows them to exploit new business opportunities in international markets. Factors highlighted include the level of experience the entrepreneur or the management team possesses (Oviatt and McDougall, 2005), the director's strategic orientation (McDougall and Oviatt, 2000; Dimitratos and Jones, 2005) or the entrepreneur's ability to form and manage personal and business relationships (Autio et al., 2005; Fernhaber and McDougall, 2005; Godesiabois, 2005).

A decade after the seminal paper published by Oviatt and McDougall (1994), Zhara (2005) and Autio (2005) identified the need to refocus research in this field towards understanding the factors that could explain international performance in INVs. From a resource-based theory perspective, differential endowment of organisational resources is an important determinant of strategy and performance. Resources include assets, capabilities, information, knowledge, technologies and so forth, controlled by the company and enabling it to conceive and implement strategies that improve its effectiveness and efficiency (Collis, 1991). However, given the scarce resources typical of INVs, Zhara (2005) and Autio (2005) argue that the performance of INVs cannot be based on tangible resources. It would appear more logical to consider INVs' success as being based on their skills in generating and developing a set of valuable intangible resources and capabilities that allows them to compete internationally in their sector. In this vein, INVs have been associated with a high level of technological capabilities (Autio et al., 2000; Oviatt and McDougall, 2005), relational capabilities (Autio et al., 2000, 2005; Fernhaber and McDougall, 2005) and strategic adaptation capabilities (Fernhaber and McDougall, 2005; Zheng and Kavul, 2005). More recently, Oviatt and McDougall (2005) and Weerawardena et al. (2007) have indicated that market knowledge and the processes by which marketing capabilities are developed can also be significant to understanding the success of INVs, and highlight the need for further research in this area.

In his seminal contribution, Day (1994) defines marketing capabilities as the skills and competences a firm possesses that help it to understand the changes taking place in its markets together with those that enable it to operate more effectively in that market. Concretely, the author identifies three types of marketing capabilities: outside-in capabilities, inside-out capabilities and spanning capabilities. Outside-in capabilities are the firm's skills and competences that help it to understand changes taking place in its markets, together with those that enable it to operate more effectively in that market place. These marketing capabilities include market sensing capabilities such as market 
research, and market bonding capabilities such as customer relationship management. Inside-out capabilities focus on the firm's internal resources and capabilities such as financial management, cost control, technology development and integrated logistics. Spanning capabilities are those skills and competencies that serve to integrate inside-out and outside-in capabilities. They typically require both an understanding of market requirements and the internal competencies to meet them. Spanning competencies include information sharing and dissemination throughout the organisation, coordination mechanisms to integrate market knowledge into internal processes and activities such as new product/service development that require market input as well as internal technical competence.

This definition of marketing capabilities has been widely used in the specialised literature due to its emphasis on learning and on the firm's absorptive capacity (Weerawardena, 2003; Greenley et al., 2004; Vorhies and Morgan, 2005). Furthermore, in the last decade, the literature has attempted to incorporate a relational focus into the conceptualisation of marketing capabilities, as seen in studies that include relational capabilities as a further type of marketing capability (Hooley et al., 2002; Butler et al., 2003). These capabilities highlight the skills firms generate to create, maintain and exploit strategic alliances both within and across industries and the ability to create mutual trust and commitment between partners, as well as sharing expertise and more tangible assets.

In the international context, marketing capabilities can be significant for INVs' success since they are related to the skills needed to understand the factors that affect the global competitiveness of their markets. INVs initiate their international activity with a new business project, logically based on a set of conjectures that the entrepreneur makes about the future viability of his or her business idea. Because entrepreneurs cannot be certain that their business opportunities will generate profits or losses when they take the decision to act, these conjectures are necessary (Shane, 2003). During the setup phase, INVs will face changes in certain factors of their international environment and unforeseen circumstances that will require slight modifications to the initial project (Greiner, 1972). Success will therefore depend on the INV's capability to identify and adapt to the changes required by the international business opportunity, once activity has begun (Fernhaber and McDougall, 2005). Hence, INVs that develop marketing capabilities will be able to react rapidly and opportunely to the demands required by the changes that can occur in their global environment.

In addition, once the first years of activity have been successfully weathered, INVs must be capable of identifying and developing new business opportunities in international markets to ensure their success continues (Autio et al., 2000; Fernhaber and McDougall, 2005). The development of outside-in capabilities, inside-out capabilities, spanning capabilities and relational capabilities provides INVs with a greater understanding of all the factors that can affect the evolution of their environment, which in turn can impact on their capabilities to develop more realistic assumptions about new business opportunities and their viability in international markets (Fernhaber and McDougall, 2005). Thus, marketing capabilities can play a role in helping INVs develop proactive behaviour to exploit new business opportunities more successfully and more quickly than their competitors (Weerawardena, 2003).

Furthermore, marketing capabilities can help INVs to compete more effectively in each foreign market. It would seem reasonable to assume that INVs will not challenge global competitors, particularly during their first years of activity; rather they are more 
likely to have to compete at a local level. To be successful, INVs must be capable of both integrating their activity in such a way that they can obtain advantages from a global offer, and also of being sensitive to local factors that will guarantee their success in each foreign market. This competitive behaviour seems to bear similarities to the transnational approach (Bartlett and Ghoshal, 1989) or to the development of complex global behaviour as described by Porter (1986). Obviously, the challenges facing INVs will be different from those faced by multinational companies that take a transnational approach. However, like multinationals, INVs must learn to think globally but compete locally. Thus, marketing capabilities can also be key factors to understanding how INVs can successfully compete locally and, therefore, can influence their international geographical diversification and their success in each market. INVs appear to have an international behaviour that might contradict that predicted by gradualist approaches, which associate the firm's international geographical diversification with the concept of psychological distance (Johanson and Wiedersheim-Paul, 1975; Coviello and Munro, 1997). The concept of psychological distance refers to the distance the entrepreneur perceives between countries in terms of language, culture, political systems, etc., factors that hinder the flow of information between the firm and the countries in which its markets are located (Johanson and Wiedersheim-Paul, 1975). Thus, the firm begins its international activities in markets that are more similar in these aspects and are consequently perceived to be less uncertain. Once the firm has acquired greater international experience, it then considers moving into markets that are less similar in the aspects mentioned above (Johanson and Wiedersheim-Paul, 1975; Johanson and Vahlne, 1977, 1990). However, geographical proximity and psychological distance do not seem to be such significant factors in the case of INVs (Boter and Holmquist, 1996; Keeble et al., 1996; Madsen et al., 2000, Bell et al., 2004). In this vein, Andersson (2004) concludes that the concept of physical distance, while it could still be applied at industry level, must be used with great caution at individual firm level, since other factors may be given more weight in the market selection process.

Scarcity of resources once again suggests that the decision INVs take about the number of foreign markets in which they can be present may be associated with the intangible resources and capabilities that can be easily transferred between markets (Gleason et al., 2007), such as marketing capabilities. The development of marketing capabilities by INVs, the purpose of which is to seek superior value for the customer, implies developing greater sensing skills to detect the specific features of each foreign market in order to respond and adapt to them (Mazaira et al., 2005). Thus, skills related to market information processing on which INV marketing capabilities are built and developed provide the firm with information about its customers and competitors in each foreign market (Slater and Narver, 1995), thereby reducing the uncertainty associated with the international diversification of its activities and, hence, leading to a greater foreign presence. The development of marketing capabilities may give INVs more international exposure, thus diversifying their presence in foreign markets (Yeoh, 2004). In addition, marketing capabilities may also help INVs to compensate for their lack of international experience (Coviello and Martin, 1999; Ellis and Pecotich, 2001), increase their credibility in foreign markets (Zain and Imm, 2006) and give entrepreneurs in these firms a perception of lower risk and lower costs associated with international activities (Eriksson et al., 1997). 
In addition, although scarcity of resources is typical in INVs, they can use their social and business networks to obtain the resources they need to operate quickly in diverse international markets. Oviatt and McDougall (1994) highlight the importance of social and business networks as a source of resources for INVs. Indeed, the management and development of networks implies fostering skills with a strong marketing approach (O'Driscoll et al., 2000). Moreover, INV marketing capabilities, through relational capabilities, can contribute to their integration in social or business networks as a channel for sharing market information and other resources (Elg, 2002, 2008; Trulsson, 2002). Trulsson (2002) also reports that INVs can benefit from the advantages gained from this association as a means of achieving growth in international contexts.

In summary, marketing capabilities appear to be a fundamental element in understanding INV behaviour, since they enable these firms to develop transnational behaviour. These capabilities are also necessary to define the firm's global business opportunity, as well as contributing to its ability to successfully compete by adapting its offer to the specific needs of each market. Consequently, in this paper, we develop a model that explores the factors that can encourage the development of marketing capabilities in INVs, together with the factors that intervene in the relationship between their marketing capabilities, international economic performance and geographical distribution. Specifically, the paper argues that marketing capabilities must be specifically integrated into an international marketing strategy if these effects are to be achieved.

\subsection{Rapid internationalisation and marketing capabilities in INVS}

Gradualist approaches assume that the firm's experience (at home and abroad) influences its ability to develop the marketing capabilities necessary to guarantee its internationalisation (Bilkey and Tesar, 1977; Johanson and Vahlne, 1977, 1990; Cavusgil, 1980). However, some studies appear to suggest that a firm's domestic experience may not only restrict its capability to acquire and interpret new information from the international market, but may also present an obstacle to designing actions in accordance with that information (Cohen and Levinthal, 1990; Erikson et al., 1997; Hitt et al., 1997; Wagner, 2004). Firms that are set up to be successful in international markets must develop new internationally oriented marketing capabilities (Erikson et al., 1997). This process is neither simple nor immediate, since the marketing capabilities required for international operations may come into conflict with the organisational processes and systems that already exist in the firm. There may be a risk that established firm managers will limit their analysis to factors they are familiar with when developing the sensing capabilities required to successfully compete in foreign markets. Or this information may be assimilated into the firm only in so far as it does not conflict with the existing knowledge base, thus causing difficulties in the development of spanning capabilities. The firm will probably attempt to reproduce the customer relations processes and systems developed in domestic markets in its international market. Such behaviour would limit the firm's ability to develop a set of marketing capabilities needed to carry out its international activity (Zahra and George, 2002; Eriksson and Chetty, 2003). Autio et al. (2000) confirm that the older the firm, the more cognitive, political and relational obstacles are likely to be present, thereby causing difficulties in the development of new systems and processes. Domestic experience can therefore have a negative effect on the 
development of the marketing capabilities required to compete in the new international environment.

INVs, created for international operations, can establish routines to manage these factors, to coordinate resources internationally and to sell in different countries from the beginning of their commercial activity (Oviatt and McDougall, 1994; McDougall et al., 1994). Rapid entry into international markets promotes their international identity (Autio et al., 2000). INV directors design their firms, systems and processes with a focus on the foreign market (Sapienza et al., 2005). From setup, these firms devise all the processes necessary to develop outside-in, inside-out, relational and spanning capabilities in accordance with the characteristics of their international markets. The study by Blomstermo et al. (2004) demonstrates that INVs' absorptive capacity structure is different from firms that follow slower internationalisation processes in that it favours the development of marketing capabilities. This paper therefore posits a positive relationship between early internationalisation in INVs and the development of international marketing capabilities.

H1 Rapid international entry by new firms has a positive effect on the development of marketing capabilities in international markets.

\subsection{Marketing capabilities and international marketing strategy in INVS}

In order to compete in each foreign market, the firm should design an international marketing strategy that guarantees success in that market. Antecedent factors influencing the firm's international marketing strategy have been grouped into environmental, market, customer, competition, product/industry, organisational and managerial factors (Theodosiou and Leonidou, 2003). However, little attention has been devoted to company capabilities as an antecedent of international marketing strategy.

The importance of information as a key factor affecting a firm's international behaviour has long been acknowledged in the international marketing literature (Diamantopoulos, 2003). International firms use export information to overcome decision-making uncertainty caused by the potentially unfamiliar environment, and this information acts as an essential prerequisite to making successful business decisions (Vyas and Souchon, 2003). The desire to acquire new knowledge and new skills has also been shown to be of great importance for internationalisation (Burpitt and Rondinelli, 2000).

To overcome the challenges associated with international activities (Zaheer, 1995), INVs should take decisions on the characteristics of the product, on distribution channels and on appropriate communication choice in such a way that they are able to define an offer that satisfies their customers' needs in their chosen market more successfully than their competitors. These decisions require a firm to develop business processes that facilitate the information and knowledge about the markets in which the firm is going to compete. Only with this information will INVs be able to develop an international marketing strategy superior to that of their competitors.

According to Day's (1994) definition of marketing capabilities, the firm's learning and absorptive capacities are key components of these capabilities (Weerawardena, 2003; Greenley et al., 2004; Vorhies and Morgan, 2005; Blesa et al., 2007). Marketing capabilities are essential in determining which marketing actions can help INVs to 
compete successfully in different international markets. Marketing capabilities enable INVs to tailor their offer to the needs of their clients in foreign markets, to communicate their offer in the right way, to choose the most efficient distribution channels in these markets and to be able to establish a price that reflects the value of their product in the international market (Douglas and Wind, 1987; Douglas and Craig, 1989; Walters and Toyne, 1989; Weerawardena et al., 2007).

In this vein, several researchers provide evidence that a firm's capabilities have a major influence on marketing strategy choice (Stopford and Wells, 1972; Aaker, 1988; Dunning, 1988; Kim and Hwang, 1992; Lim et al., 1993; Cavusgil and Zou, 1994). Indeed, Chen (1999) shows that the possession of superior marketing capabilities profoundly influences the firm's development of international marketing strategies. Hence,

H2 Marketing capabilities positively influence the development of an international marketing strategy in INVs.

\subsection{The influence of an international marketing strategy on the international geographical diversification of INVS}

The literature suggests that an increasing number of small firms are diversifying their international markets (Yeoh, 2004; Zain and Imm, 2006). Although some scholars argue that INVs follow an accelerated gradual process (Hashai and Almor, 2004), most of these authors consider that INVs characteristically operate simultaneously in various foreign markets (Cooper and Kleinschmidt, 1985; Ayal and Raban, 1990). Thus, INVs are less dependent on established businesses in specific regions, as they tend to focus on specific market niches rather than specific geographical regions (Bell, 1995; Madsen et al., 2000). However, INVs do compete locally with established competitors in their foreign markets. This transnational behaviour obliges the INV entrepreneur to develop business processes that allow resources developed at a local level to be used on a global scale (Bartlett and Ghoshal, 1977). In this context, the development of an international marketing strategy that facilitates the satisfaction of a local demand can help the INV entrepreneur become familiar with the various marketing decisions that he or she should adopt in order to compete successfully in the new market, which in turn helps to improve the INV's international learning behaviour. This learning process gives INVs the knowledge on how to operate internationally. This international knowledge refers to how the firm manages market information and transforms it into concrete actions to bridge the interface between the firm and its international markets (Eriksson et al., 1997). It is firm-specific knowledge, which integrates and coordinates all the firm's internationalisation activities, including the search for and transmission of business and institutional knowledge (Blomstermo et al., 2004). Not only does it reduce the possibilities of failure on entering new markets, but also lowers the perception of risk that entrepreneurs have about entering new markets and therefore, their willingness to do so (Eriksson et al., 1997). The development of international marketing strategies can thus lead INV entrepreneurs to adopt a more positive attitude towards new foreign markets (Brush, 1992), allowing INVs to gain greater international exposure and thus diversifying their presence in foreign markets (Yeoh, 2004). We therefore propose that: 
H3 The marketing strategy adopted by INVs will influence their international geographical diversification.

\subsection{The influence of the international marketing strategy on the international performance of new firms}

Numerous studies have discussed the relationship between the firm's marketing strategy and its performance (Buzzell and Gale, 1987; Lim et al., 1993; Cavusgil and Zou, 1994), finding that marketing strategies are associated with superior performance levels (Buzzell and Wiersema, 1981; Slater and Narver, 1994). Superior product innovation leads to higher market shares (Manu, 1992). Likewise, a marketing orientation can lead to superior business performance by meeting the customer's needs (Avlonitis and Gounaris, 1997).

In the context of international marketing, many studies (e.g., Christensen et al. 1987; Cavusgil and Zou, 1994) have suggested that export performance is influenced by the export marketing strategy. This strategy encompasses all the factors of the conventional marketing plan, including those related to the product, price, promotion and distribution. Thus, in contrast to other previous export-related studies that defend the existence of direct effects on international performance deriving from the product, the industry and the characteristics of the foreign market, Cavusgil and Zou (1994) highlight the central role of marketing strategy in determining firm performance.

Product adaptation and promotion, together with competitive pricing strategies, have been reported as ways in which firms adapt and modify their offers to different international markets (Douglas and Wind, 1987; Douglas and Craig, 1989; Walters and Toyne, 1989). Consequently, the strategies the firm develops will be expected to influence its international performance. Specifically, the literature provides empirical evidence of a positive relationship between performance and product adaptation (Hill and Still, 1984), promotion adaptation (Killough, 1978), competitiveness through prices (Christensen et al., 1987) and in general, marketing strategies (Cooper and Kleinschmidt, 1985; Chen, 1999).

In the case of INVs, the marketing strategies factor takes on greater importance since these firms not only have to face the challenge of newness, with the limited resources and experience that this implies, but they also have to compete with firms that are already established and consolidated in the foreign market they are operating in (Autio et al., 2000). The definition of an appropriate marketing strategy will therefore be crucial in determining the success of INVs in their markets, since this strategy must be reflected in innovative distinctive products at competitive prices, distributed and promoted using alternative, effective ways that will guarantee the firm's competitiveness from the first moment it enters a new market. Furthermore, the above-mentioned limitations of INVs may in certain cases be regarded as advantages, since young firms, unlike their mature established competitors, are not rigidly anchored to a set of particular routines. The capacity of these mature consolidated firms to respond to new factors that can emerge as a result of the firm's international activity will be limited (Zahra and George, 2002; Eriksson and Chetty, 2003).

In accordance with these arguments, we propose that the international marketing strategy will have a positive effect on the international economic performance of new firms in their foreign markets. 
H4 The international marketing strategy will have a positive influence on the international economic performance of new firms.

Figure 1 shows the theoretical model proposed in this study and the hypotheses presented above.

Figure 1 Model of the effects of marketing capabilities as a determining factor in understanding the competitive consequences of rapid international entry

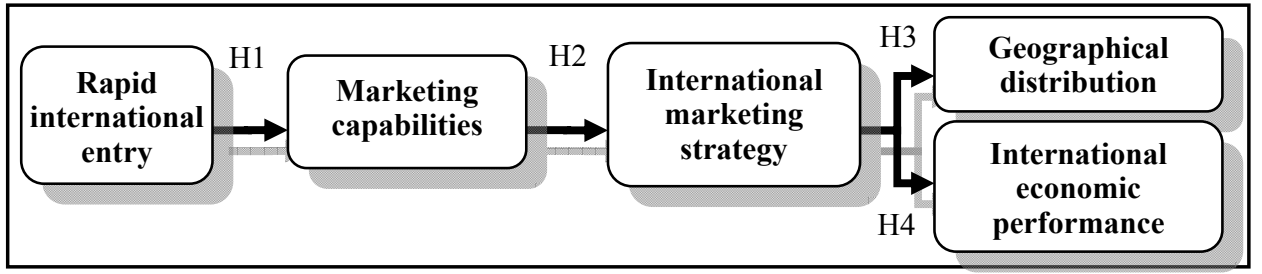

\section{Methodology}

\subsection{Sample selection and data collection}

To test the hypotheses posited in this study, a total of 537 Spanish INVs were selected from a wide range of sectors. We used the 2002 Duns and Bradstreet database, which contains around 850,000 Spanish firms. Three criteria were applied to the database in order to select new firms that had internationalised shortly after creation (Coviello and Jones, 2004). The first was recent creation. Although Oviatt and McDougall's (1994) definition suggests that INVs should be international from inception, in general, the period of time considered to define an INV varies from three years (Madsen and Servais, 1997), six years (Zahra et al., 2000), seven years (Jolly et al., 1992) up to more than eight years (McDougall and Oviatt, 1996) after setup. Inline with the above, firms selected for the sample were required to have been created no more than seven years previously. The second criterion was that firms should be engaged in international activities; firms whose level of exports was over $25 \%$ of their annual sales were considered to have a consolidated international presence. The third criterion was that firms should take their own strategic decisions, which excluded subsidiary or affiliated firms.

Following an extensive review of the literature, a questionnaire was prepared and a pre-test carried out through personal interviews with managers from a pilot sample of 25 INVs to ensure that the questionnaire was fully comprehensible. As no problems of understanding were detected during the pre-test, the initial questionnaire was not modified. An electronic version was then prepared to facilitate and broaden channels of response for the interviewees. Initial telephone contact was established to request the collaboration of the firm's director, together with his or her e-mail address. Each interviewee then received an e-mail requesting collaboration and containing a link to the questionnaire website. Periodic telephone contact was subsequently made to non-responding firms in order to improve the response rate. The sampling process was undertaken in the last quarter of 2005; 135 valid responses were obtained, representing a response rate of $25.14 \%$. 
The average age of the firms selected was 4.38 years (S.D. 1.68), with international activity initiated 3.9 years previously (S.D. 1.61). The firms had an average of around 26 employees; $24.5 \%$ of the firms had an annual turnover of below $€ 800,000,47.9 \%$ between $€ 800,000$ and $€ 5$ million, and $27.6 \%$ had an annual turnover of over $€ 5$ million.

Non-response bias was controlled for by comparing the first and the last questionnaires to be completed. A t-test analysis showed no significant differences at the 0.05 level, confirming the absence of non-response bias (Armstrong and Overton, 1977). Likewise, in order to verify that the characteristics of the sample did not influence the effects on the main results of the variables, a MANOVA was performed, taking sector, age, size (turnover and employees) and international activity as independent variables. The results of the analysis revealed no significant differences at the 0.05 level in any of the model variables.

\subsection{Measurement instruments}

In order to measure marketing capabilities, we adapted the scale developed by Hooley et al. (2002) to the international context. This marketing capabilities scale has also recently been suggested by Weerawardena et al. (2007) for application in the specific context of INVs. The scale identifies four dimensions in marketing capabilities based on the typology proposed by Day (1994), with the inclusion of a new factor corresponding to relational capability. Thus, marketing capabilities were grouped as follows: outside-in capabilities, inside-out capabilities, spanning capabilities and relational capabilities (Table 1).

Table 1 Measurement of marketing capabilities

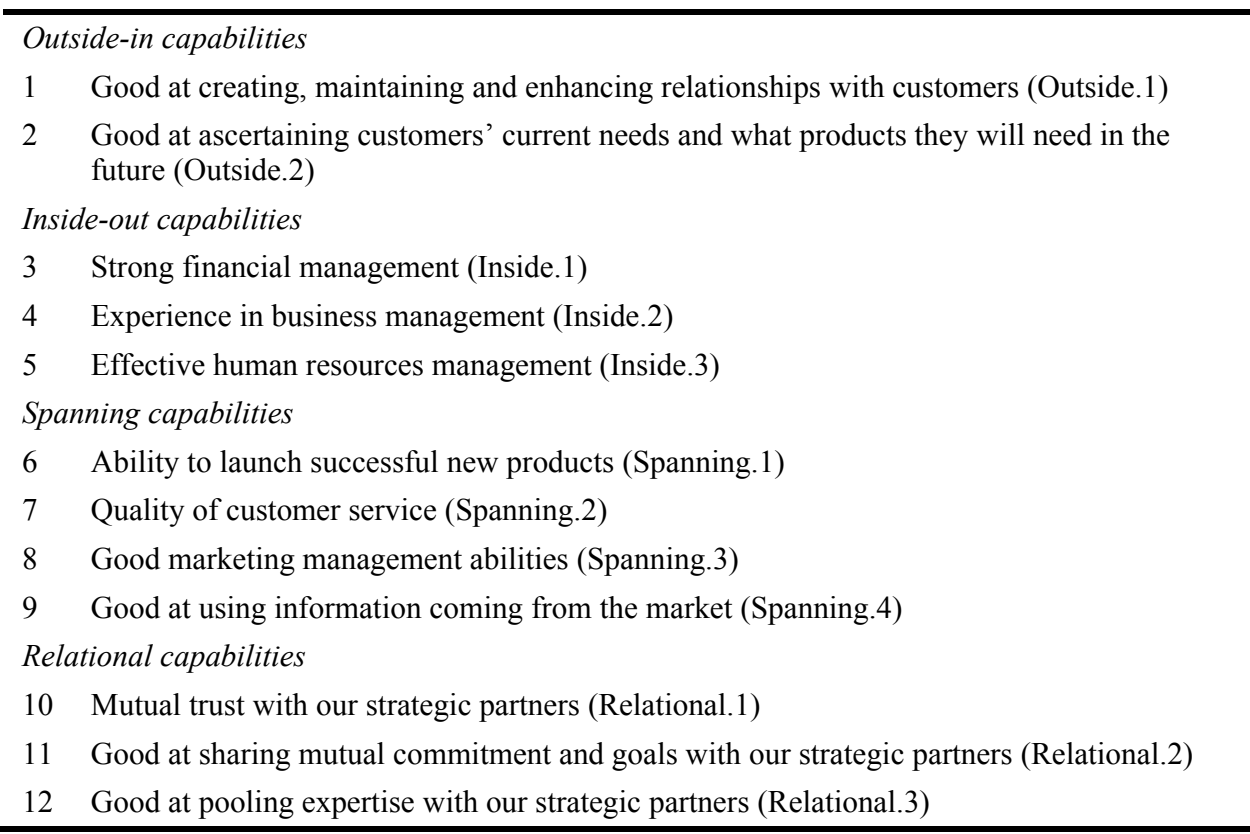

Taking the works of Leonidou et al. (2002) and Leonidou (2004) as a reference to measure international marketing strategy, directors were asked to comment on the 
relative position of their firm in their principal foreign market as compared to their most important competitors in that market, in areas of competition concerning product, service, price, communication and distribution (Table 2). Following other authors (Burgel and Murray, 2000; Johnson, 2004), in this study we decided to refer questions on marketing strategy and international performance to the principal foreign market in which the firm operates, thus aiding interviewee recall. However, this should be taken into account when interpreting the results of this study.

Table 2 Measurement of international marketing strategy

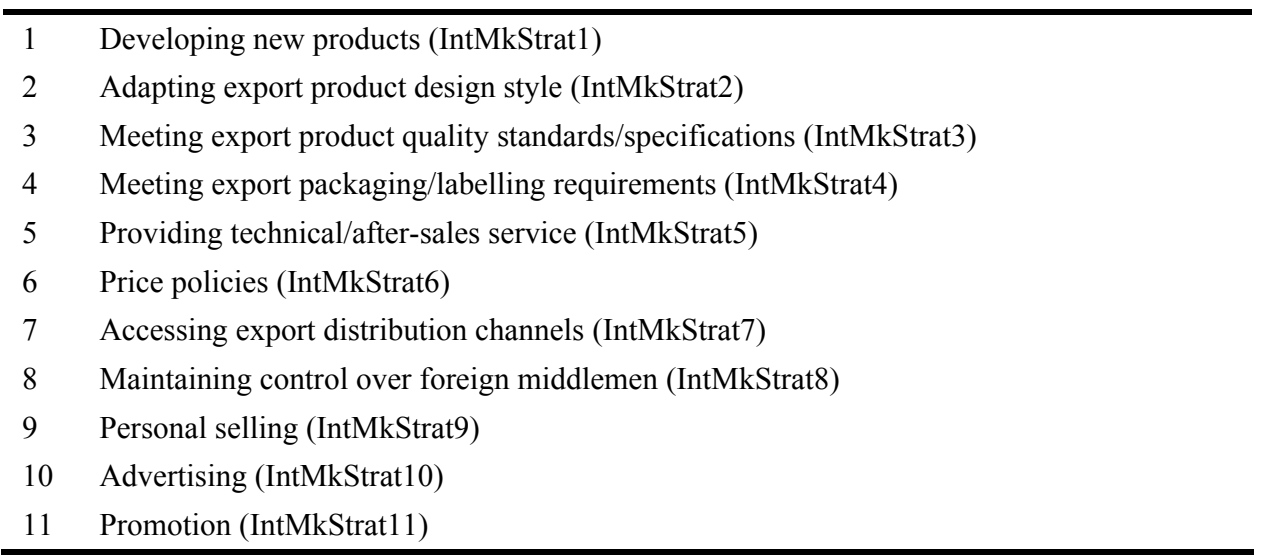

To avoid confusion over terminology, we consider it pertinent to clarify that the term 'rapid international entry' used in this work can be considered as synonymous with other terms used in the literature such as the speed of first entry into international markets (Oviatt and McDougall, 2005) or the precocity with which international operations are undertaken (Zucchella et al., 2007). All the firms included in the sample were INVs and had begun international activity within the first seven years following creation. In fact, the firms on average initiated international activity after their first year in operation. In this situation, the measurement of rapid international entry as the number of years between creation and beginning international activities may not reveal any differences between the firms, as demonstrated by the ANOVA performed between this variable and other constructs. Consequently, it was decided to measure the speed with which engagement in international markets occurred according to the percentage of foreign activity these INVs had at the time of interview. In this line, Hurmerinta-Peltomaki (2002) indicates that rapid international entry is not only reflected by the number of years the firm takes to enter the foreign market, but also by the level of international commitment reached during that period. In the same time period, this indicator shows how rapidly new firms committed resources in their international activities; thus, if during the same period, the percentage of a firm's international activity is above, for example, $50 \%$, it can be considered to have internationalised more quickly than a firm that carries out no more than, for example, $25 \%$ of its activity abroad. The percentage of activity carried out abroad was obtained for each one of the following activities of the firm's value chain: manufacture, research and development, marketing, publicity and promotion, and after-sales service.

In addition, the geographical distribution of the markets of INVs was determined by asking directors to indicate the number of countries in which their firm was present. 
Firms engaged internationally in a higher number of countries had a greater geographical distribution.

A review of the literature suggests that the two main ways to evaluate business performance are through objective and subjective measures (Katsikeas et al., 1996). The use of objective indicators in the international sphere may not be very useful for making comparisons between firms and between countries, due to differences in terms of competition, technological intensity, market structure (Katsikeas et al., 1996), accountability and sales (Styles, 1998). For this reason, an increasing number of researchers now use subjective measures to evaluate firms' international performance. Evidence also exists of positive correlations between subjective and objective measures (Shoham, 1998; Styles, 1998). The use of subjective measures also has the advantage of simplifying data collection (Shoham, 1998). These arguments appear to support the adoption of subjective measures to evaluate the international economic performance of new firms. Consequently, we opted to consider three general indicators of business performance at an international level; directors were asked about their firm's position in their main foreign market as compared to their main competitors in the same market with regard to return on investment $(\mathrm{ROI})$, profits and market share.

\subsection{Scale validity and reliability}

There are four critical issues in the appropriate construction of formative indices (Diamantopoulos and Winklhofer, 2001): content specification, indicator specification, indicator collinearity and external validity. In order to check the content and specification of the business economic performance indicators, all the items were taken from the review of the related literature, confirming that all the relevant dimensions of the construct were included. The analyses of multicollinearity between the indicators of the various indices show that the maximum factors of variance inflation in the international economic performance index (4.285) is below the commonly accepted threshold of ten (Kleinbaum et al., 1988). Finally, following the recommendations of Jarvis et al. (2003) for external validity evaluation, two reflective indicators were added to the formative construct and a model of multiple indicators and causes was estimated for this index. Table 3 shows the reflective indicators and the estimation of the model, which present a good overall fit.

Table 3 External validity of the international economic performance index

\begin{tabular}{|c|c|c|c|c|c|c|c|c|c|}
\hline \multicolumn{2}{|c|}{ Reflective indicators } & \multicolumn{8}{|c|}{ Goodness-of-fit measures } \\
\hline 1 & $\begin{array}{l}\text { In general, my firm } \\
\text { obtains good results }\end{array}$ & $\chi^{2} / \mathrm{fd}$ & RMSR & GFI & AGFI & NFI & CFI & IFI & RFI \\
\hline 2 & $\begin{array}{l}\text { My firm is a } \\
\text { successful business }\end{array}$ & 1.13 & 0.020 & 0.99 & 0.94 & 0.99 & 1.00 & 1.00 & 0.96 \\
\hline
\end{tabular}

The reflective scales (marketing capabilities and international marketing strategy) were refined by performing a confirmatory factor analysis using structural equations. Specifically, we used the procedure known as 'model development strategy' (Hair et al., 1999). In this way, starting with structures of latent variables assumed for the two constructs, an improvement process was undertaken that allows the initial models to be perfected by suppressing the least appropriate indicators. Thus, following the recommendations of Jöreskog and Sörbom (1993), the estimation parameters were first 
examined. Indicators that did not meet the 'strong convergence criterion' (Steenkamp and Van Trijp, 1991) were eliminated. This criterion must be analysed by observing how substantial the loadings are. Indicators with standardised coefficients $(\lambda)$ lower than 0.45 (Hildebrant, 1987) are considered insubstantial, and therefore can be eliminated. Secondly, we verified whether the 'weak convergence criterion' (Steenkamp and Van Trijp, 1991) was met by analysing the significance of the factor regression coefficients between the indicators and their corresponding latent variables. To do this, the value of the student's $t$ statistic was reviewed by imposing the maximum requirement $(t>2.58$; $\mathrm{P}=0.01)$. Compliance with this requirement guaranteed that all the indicators were significantly related to their corresponding latent variable. A third criterion, wholly related to the first, was to sequentially eliminate any indicator that, although meeting the above-mentioned criteria, did not reach a minimum strength in its corresponding linear relationship. Because this characteristic was measured by the $\mathrm{R}^{2}$ observed for each relationship, the $R^{2}$ was required to reach a minimum value of 0.20 . The application of this third criterion guaranteed the elimination of indicators that presented a higher proportion of variance due to errors and were therefore not sufficiently explained by the factor with which they were assumed to be related. Application of these criteria led us to eliminate the Inside. 2 and Spanning.4 indicators from the marketing capabilities scale.

A series of tests was then performed to check that the scale refinement process described above had not impaired scale reliability. One diagnostic measure of internal consistency is the 'reliability coefficient' that evaluates the consistency of the whole scale, for which Cronbach's alpha (Nunnally, 1979) is the most extensively used measure. Other complementary reliability tests were also performed: 'composite reliability' of the construct and an analysis of 'average variance extracted'.

The confidence interval test was applied to evaluate 'discriminant validity'; this consists of verifying that the value ' 1 ' does not lie within the confidence intervals estimated for the correlations between each pair of dimensions.

Table 4 summarises the main results of the reliability and validity analyses of the marketing capability and international marketing strategy scales.

Table 4 Summary of the reliability and validity analyses of the scales

\begin{tabular}{|c|c|c|c|c|c|c|c|c|}
\hline \multicolumn{3}{|l|}{ Scale } & \multicolumn{2}{|c|}{ Marketing capabilities } & \multicolumn{4}{|c|}{ International marketing strategy } \\
\hline Param & & & \multicolumn{2}{|c|}{$0.49-0.94$} & \multicolumn{4}{|c|}{$0.48-0.67$} \\
\hline$\alpha$ & & & \multicolumn{2}{|c|}{0.714} & \multicolumn{4}{|c|}{0.838} \\
\hline $\mathrm{CR}$ & & & \multicolumn{2}{|c|}{0.92} & \multicolumn{4}{|c|}{0.83} \\
\hline VE & & & \multicolumn{2}{|c|}{0.53} & \multicolumn{4}{|c|}{0.46} \\
\hline \multicolumn{9}{|c|}{ Goodness-of-fit measures } \\
\hline$\chi^{2} / g l$ & RMSEA & $N F I$ & CFI & $I F I$ & $R F I$ & $R M S R$ & $G F I$ & $A G F I$ \\
\hline 1.83 & 0.079 & 0.94 & 1.00 & 1.00 & 0.92 & 0.066 & 0.96 & 0.94 \\
\hline
\end{tabular}

In light of these results, although the value of the variance extracted in the marketing capabilities scale falls below the optimal threshold of 0.5 , indicating that over half the variance of the specified indicators is not considered in the construct, it should be noted that the scale values are devalued to a certain extent because the minimum threshold of $\mathrm{R}^{2}$ was set at 0.20 (the minimum acceptable threshold to avoid unnecessary eliminations of indicators). Thus, the lower the $\mathrm{R}^{2}$ of the indicators, the higher the measurement errors 
associated with them will be. The denominator in the mathematical expressions that define the two statistics is therefore higher, which has the effect of lowering the results derived from the quotient. However, its value is relatively close to the optimal level, and the other two scale reliability measures present values substantially higher than the minimum recommended value of 0.7 . This reservation should however be taken into account when analysing the results.

\section{Results and discussion}

As with the scale validations, the hypotheses were tested using structural equations models. These models have proved useful when the research objective is to find the causal contributions of one variable to another in a non-experimental setting (Jöreskog and Sörbom, 1993). Furthermore, unlike techniques such as multiple regression, factor analysis, multivariate analysis of variance, etc., which only allow one relationship to be examined at a time, structural equations model (SEM) analysis can be used to simultaneously explore a series of dependency relationships (Hair et al., 1999). This technique is therefore particularly useful when one dependent variable becomes an independent variable in subsequent dependency relationships. This set of relationships, each one with dependent and independent variables, therefore forms the basis of the SEM.

Before describing the analyses carried out to test the hypotheses, it should be noted that our database had to be modified in order to use the LISREL 8.50 program, given the small size of the sample as compared to the size of the theoretical model proposed. To this end, the multidimensional marketing capabilities scale was reduced to each one of its dimensions by calculating the means of the indicators resulting from the validity and reliability analysis. Table 5 presents the results of these analyses.

Table 5 Result of testing the effects of marketing capabilities as a determining factor in understanding the competitive consequences of rapid international entry

\begin{tabular}{|c|c|c|c|c|}
\hline Rapid international entry - marketing capabilities & 0.91 & $\begin{array}{c}9.00 \\
(\mathrm{p}<0.001)\end{array}$ & $\mathrm{H} 1$ & Accepted \\
\hline $\begin{array}{l}\text { Marketing capabilities - international marketing } \\
\text { strategy }\end{array}$ & 0.91 & $\begin{array}{c}2.89 \\
(\mathrm{p}<0.01)\end{array}$ & $\mathrm{H} 2$ & Accepted \\
\hline $\begin{array}{l}\text { International marketing strategy - geographical } \\
\text { distribution }\end{array}$ & 0.15 & $\begin{array}{c}2.22 \\
(\mathrm{p}<0.05)\end{array}$ & $\mathrm{H} 3$ & Accepted \\
\hline $\begin{array}{l}\text { International marketing strategy - international } \\
\text { economic performance }\end{array}$ & 0.82 & $\begin{array}{c}7.82 \\
(p<0.001)\end{array}$ & $\mathrm{H} 4$ & Accepted \\
\hline \multicolumn{5}{|c|}{ Goodness-of-fit measures } \\
\hline$\chi^{2} / \mathrm{fd}=1.76 \mathrm{RMSR}=0.075 \mathrm{RMR}=0.080 \quad \mathrm{NFI}=0.92$ & GFI $=0.95$ & $\mathrm{AGFI}=0.91 \mathrm{Cl}$ & $=0.97$ & $\mathrm{IFI}=0.97$ \\
\hline
\end{tabular}

The results confirm all the hypotheses proposed in the model. Thus, rapid international entry is positively and significantly related to the development of marketing capabilities $(\gamma=0.91 ; t=9.00)$, and these capabilities, in turn, are positively and significantly related to international marketing strategy $(\gamma=0.91 ; t=2.89)$. These results suggest that the rapid entry of INVs in foreign markets has an indirect effect on their international marketing strategy through the development of marketing capabilities, thus confirming 
hypotheses $\mathrm{H} 1$ and $\mathrm{H} 2$. Moreover, as proposed in hypotheses $\mathrm{H} 3$ and $\mathrm{H} 4$, international marketing strategy positively influences international geographical diversification $(\gamma=0.15 ; \mathrm{t}=2.22)$ and the international economic performance of INVs $(\gamma=0.82$; $\mathrm{t}=7.82)$.

This study has developed the concept of 'learning advantages of newness' proposed by Autio et al. (2000, p.919). Specifically, we have attempted to study the influence rapid entry in new foreign markets can have in new firms. Results confirm that rapid entry in foreign markets can help INVs overcome the limitations deriving from scarce resources typical in these firms, since this encourages INVs to develop their marketing capabilities. Marketing capabilities enable INVs to obtain greater knowledge about the generators of international competition, but at the same time allow them to design an international marketing strategy adapted to the needs of each market.

Hence, the marketing capabilities developed by INVs further our understanding of the transnational behaviour of these firms. As Oviatt and McDougall (2005) or Weerawardena et al. (2007) suggest, this study has shown that marketing capabilities constitute a fundamental factor in understanding the way in which rapid internationalisation of new firms has positive effects on the geographical diversification of their international markets and their economic performance. This study therefore allows a further organisational capability to be added to the list of those which appear to be significant to INV success, namely technical capabilities, relational capabilities or strategic adaptation capabilities (Fernhaber and McDougall, 2005). The study also complements the findings of Morgan et al. (2006), who identified five capabilities associated with firms that follow rapid internationalisation processes. Specifically, these authors indicate that INVs develop reputation, financial, human, cultural and relational capabilities. The present study allows us to add marketing capabilities to this list.

Furthermore, the model proposed indicates that the positive influence of marketing capabilities on international performance and international geographical diversification require the presence of an international marketing strategy that transforms these capabilities into concrete actions for application in international markets, thus facilitating the development of a transnational strategy. The present study has therefore extended the marketing strategy and international performance literature in two distinct ways. Firstly, the empirical relationship between international marketing strategy and performance has been corroborated in the context of INVs, an area traditionally ignored by marketing research. Our results support the idea that these firms can achieve superior performance in international markets by means of an international marketing strategy based on marketing capabilities generated in the firm. Secondly, the study gives us a more in-depth understanding of the factors for INVs' success in foreign markets.

The study also provides empirical evidence that the rapid international entry characteristic of INVs contributes to their international economic performance and their international geographical diversification. Hence, these results not only corroborate Autio et al.'s (2000) most recent findings of a positive relationship between this rapid entrance and international growth of new firms, but also demonstrate that INVs improve their position in their principal foreign market as compared to their main competitors in terms of ROI, net profits, market share and international geographical diversification. Rapid entry in foreign markets therefore appears to contribute to developing the marketing capabilities INVs need to be able to design a strategy that allows them to integrate the advantages of their global business with the need to operate locally. In other words, rapid entry in foreign markets influences the way in which these firms acquire information and 
knowledge from foreign markets, together with the way they process this information and generate actions according to it in order to respond with an offer that satisfies their local customers' needs more effectively than their competitors. The possibility that rapid international entry in INVs may be a factor that can affect their capacity to acquire new knowledge about international markets and successfully compete in them contrasts with one of the hypotheses put forward by the gradualist models of internationalisation. In these models, firm experience and physical presence in foreign markets are considered to play an essential role in explaining how firms acquire tacit market knowledge (Bilkey and Tesar, 1977; Johanson and Vahlne, 1977, 1990; Cavusgil, 1980).

\section{Conclusions, limitations and future research lines}

This study was carried out as an initial attempt to address the main unknowns in the current internationalisation literature concerning the relationship between rapid international entry, international performance and international geographical diversification in new firms.

However, when analysing the study results, we should bear in mind that the factors intervening in both the economic performance and the international geographical diversification of INVs are highly diverse, and in order to understand them an integral approach is required that enables us to analyse the relationships between all the determining factors (Crick and Jones, 2000; Coviello and Jones, 2004; Crick and Spence, 2005), such as the model proposed by Oviatt and McDougall (2005). Nonetheless, our study has demonstrated the influence of rapid international entry on international economic performance and international geographical diversification in INVs through its effect on the development of international marketing strategies based on marketing capabilities.

From an educational perspective, the conclusions of this study suggest that business schools should provide their students with the tools required to rapidly take advantage of the business opportunities that present themselves in an international sphere. Similarly, from a business point of view, entrepreneurs who are considering the possibility of developing businesses abroad should be aware that rapid entry in international markets can help them to generate marketing capabilities, which can serve as a base for the adoption of an international marketing strategy that can have positive effects on their internationalisation. It should also be borne in mind that our economy is immersed in a global environment characterised by unrelenting technological advance, intense competitiveness and consumers with constantly changing tastes and preferences. These circumstances may place a new firm in a situation of instability, a situation that requires the new firm to develop and adopt certain mechanisms that will enable it to obtain and generate information about its foreign market for subsequent analysis and the selection of an innovative and proactive response that will help the firm to adapt proactively to market demands. The present study considers that rapid international entry and marketing capabilities and strategies are key factors that can help INVs face this dynamic environment competitively. From a political point of view, our findings should be interpreted in terms of how they can enable political managers to further their understanding of the factors that can contribute to the success of INVs, which will impact on the development of measures and programmes of support that best reflect the situation of INVs. 
However, the conclusions drawn in this study should be considered in the light of its limitations. Firstly, our empirical study is based on the responses of a single interviewee from each one of the sample firms ('common-method bias'). This process raises the question of whether a single interviewee can adequately answer for the whole organisation (Hogarth and Makridakis, 1981; Barnes, 1984). The firm's manager seems to be the most capable person to speak in the name of the firm (Davidsson, 2004), since he or she possesses the most in-depth knowledge of the firm's characteristics, strategy and results (Hambrick, 1981), and is familiar with all the aspects of its operations, influences strategic management and plays a key role in the decisions to adopt technology (Miller and Toulouse, 1986). The strategic data obtained from middle and lower range management is of questionable validity since these managers do not generally have access to information on how the whole system operates (Kotha and Vadlami, 1995). Similarly, many researchers state that in developing marketing strategy, it is the firm's manager who, based on his or her perceptions, formulates strategies designed to exploit market opportunities. Consequently, in a dynamic context, actions related to learning and market strategy appear to be more consistent with management perceptions than with objective criteria (Miles et al., 1974).

In addition, the use of cross-sectional data may be regarded as a study limitation when causal inferences are made. However, bearing in mind that the main explanatory variables of the proposed model are manifest in activities and behaviours embedded in the firm's routines and processes (Jantunen et al., 2005), it seems reasonable to assume a structure of causal explanation such as that used in this paper, in which capabilities and international marketing strategy have a positive impact that implies the firm obtains a superior competitive position.

In line with the above-mentioned limitations, future studies should examine the relationships proposed here using longitudinal data, and combining positivist and interpretive methods, such as ethnographic or phenomenological enquiry (Coviello and Jones, 2004). Taking these authors as a reference, the reconciliation of positivist and interpretive methodologies will lead to a greater understanding of INV behaviour.

Chetty and Campbell-Hunt (2004) analyse the extent to which INVs deviate from the conventional internationalisation model. Their research indicates that many of the factors considered to identify the internationalisation path taken by INVs are also characteristic of firms that begin internationalisation in the traditional way. Future research should therefore analyse how these two business realities differ (Bell et al., 2004; Chetty and Campbell-Hunt, 2004; Laanti et al., 2007). Thus, Gabrielsson et al. (2008) suggest the need to investigate the factors that can explain rapid international growth of new firms. These authors consider that rapid international growth is the factor that best allows us to discriminate between different international behaviours of new firms.

Furthermore, in light of the results that show INVs operate in different countries at the same time from inception, future studies should analyse the entry modes these firms use to access foreign markets. In this vein, the dearth of studies analysing the governance structures used by these firms to internationalise seems surprising (Autio, 2005; Zahra, 2005), particularly if we consider that they are new firms and despite having to overcome limitations associated with newness and foreignness, they appear to use high commitment entry modes from the beginning of their activities (Oviatt and McDougall, 1994; Aspelund et al., 2007).

The specialised literature also highlights the importance of firm networks in the creation of INVs. In their seminal paper, Oviatt and McDougall (1994) stated that this 
entrepreneurial phenomenon could not be understood without taking into account the characteristics of the entrepreneur's relationship networks. Coviello and Munro (1995) propose that a relational perspective must be taken if we are to fully understand the internationalisation process in new firms. These authors consider that the decision to operate in international markets, together with the choice of which specific markets to enter, are two decisions resulting from the opportunities created through entrepreneurs' contacts with different members in their network. One of the main advantages obtained by INVs in this setting is access to a large amount of information. INVs use their relationships to access new knowledge, and to share their own knowledge with other trusted firms. On this issue, Loane and Bell (2006) have highlighted the need for further research attention to the mechanisms and routines that allow INVs to acquire knowledge. Previous research also suggests that entrepreneurial networks play a determining role in the creation of INVs and their international growth. However, new studies are needed to analyse how the features of entrepreneurial networks influence the speed with which INVs increase their international commitments and their entry in new markets (Oviatt and McDougall, 2005; Coviello, 2006). These studies would undoubtedly lead to a greater understanding of the factors that contribute to international competitiveness in INVs. It would consequently seem pertinent to extend the scope of research into INVs to include the networks in which they participate.

Finally, based on the postulates of the resources and capabilities theory [see Newbert (2007) for a critical review of the main contributions of this theory], we can argue that INVs should complement their organisational capabilities by developing dynamic capabilities, since INVs need dynamic capabilities to develop new resources and capabilities (Barney, 1997; Teece et al., 1997). Teece et al. (1997) define dynamic capabilities as unique and idiosyncratic processes that emerge from path-dependent histories of individual firms. They include the firm's processes that use resources specifically the processes to integrate, reconfigure, gain and release resources - to match and even create market change (Eisenhardt and Martin, 2000; Schreyo and Kliesch-Eberl, 2007). Eisenhardt and Martin (2000) define dynamic capabilities as 'the organisational and strategic routines by which firms achieve new resource configurations as markets emerge, collide, split, evolve and die' (p.1107). The notion of 'dynamic' addresses the continuous renewal of organisational capabilities, thereby matching the demands of (rapidly) changing environments (Schreyo and Kliesch-Eberl, 2007). Dynamic capabilities rely more on real-time information, cross-functional relationships and intensive communication among those involved in the process and with the external market (Eisenhardt and Martin, 2000).

In addition, a review of the recent literature on dynamic capabilities reveals that three specific capabilities were most commonly used to explain the competitiveness of firms acting in dynamic environments, either as single variables or as dimensions of the generic construct of dynamic capabilities. These capabilities are: adaptive capability, absorptive capacity and innovative capacity (Wu, 2006; Pettus et al., 2007; Wang and Ahmed, 2007; Hou, 2008). Adaptive capability is defined as the firm's ability to identify and seize emerging opportunities in the market (Ansoff, 1965; Miles and Snow, 1978; Chakravarthy, 1982; Hooley et al., 1992). Cohen and Levinthal (1990, p.128) refer to absorptive capability as 'the ability of the company to recognise the value of new external information, and to assimilate and apply it for commercial purposes'. Finally, innovative capability has been widely understood to refer to the ability of an organisation to develop 
new products or markets by setting a strategic focus on innovation with innovative processes and behaviour (Ongkittikul and Geerlings, 2006; Akman and Yilmaz, 2008; Hou, 2008). However, most research into the influence of these capabilities has focused on established firms, ignoring new small and medium businesses (Zahra et al., 2006). Recent studies stress that sufficient evidence exists on the relevant influence of these dynamic capabilities on new firms operating in dynamic environments (Eisenhardt and Martin, 2000; Rindova and Kotha, 2001; Zollo and Winter, 2002; Newbert, 2005; Teece, 2007; Wu, 2009; Zhou and Li, 2009). Therefore, rapid entry in international markets might be expected to contribute to the development of dynamic capabilities in INVs. The development of dynamic capabilities in INVs will no doubt attract the attention of many researchers in the near future.

\section{References}

Aaker, D.A. (1988) Strategic Market Management, John Wiley and Sons, New York.

Akman, G. and Yilmaz, C. (2008) 'Innovative capability, innovation strategy and market orientation: an empirical analysis in Turkish software industry', International Journal of Innovation Management, Vol. 12, No. 1, pp.69-111.

Andersson, S. (2004) 'Internationalization in different industrial contexts', Journal of Business Venturing, Vol. 19, pp.857-75.

Ansoff, H.I. (1965) Corporate Strategy, McGraw-Hill, New York.

Armstrong, J.S. and Overton, T.S. (1977) 'Estimating nonresponse bias in mail surveys', Journal of Marketing Research, Vol. 14, No. 3, pp.396-402.

Aspelund, A., Madsen, T.K. and Moen, Ø. (2007) 'International new ventures: a review of conceptualizations and findings', European Journal of Marketing, Vol. 41, Nos. 11/12, pp.1423-1474.

Autio, E. (2005) 'Creative tension: the significance of Ben Oviatt's and Patricia McDougall's article: toward a theory of international new ventures', Journal of International Business Studies, Vol. 36, pp.9-19.

Autio, E., Sapienza, H.J. and Almeida, J.G. (2000) 'Effects of age at entry, knowledge intensity and imitability on international growth', Academy of Management Journal, Vol. 43, No. 5, pp.909-924.

Autio, E., Sapienza, H.J. and Arenius, P. (2005) 'International social capital, technology sharing, and foreign market learning in internationalizing entrepreneurial firms', Advances in Entrepreneurship, Firm Emergence and Growth, Vol. 8, pp.9-42.

Avlonitis, G.J. and Gounaris, S.P. (1997) 'Marketing orientation and company performance', Industrial Marketing Management, Vol. 26, No. 3, pp.385-402.

Ayal, I. and Raban, J. (1990) 'Developing hi-tech industrial products for world markets', IEEE Transactions on Engineering Management, Vol. 37, No. 3, pp.177-183.

Barnes, J.H. Jr. (1984) 'Cognitive biases and their impact on strategic planning', Strategic Management Journal, Vol. 5, pp.129-137.

Barney, J. (1997) Gaining and Sustaining Competitive Advantage, Addison-Wesley, Reading, M.A.

Bartlett, C.A. and Ghoshal, S. (1977) 'The myth of the generic manager: new personal competencies for new management roles', California Management Review, Vol. 40, No. 1, pp.92-116.

Bartlett, C.A. and Ghoshal, S. (1989) Managing Across Borders: The Transnational Solution, Harvard Business press, Boston.

Bell, J. (1995) 'The internationalisation of small computer software firms: a further challenge to stage theories', European Journal of Marketing, Vol. 29, No. 8, pp.60-65. 
Bell, J., Crick, D. and Young, S. (2004) 'Small firm internationalization and business strategy - an exploratory study of 'knowledge-intensive' and 'traditional' manufacturing firms in the UK', International Small Business Journal, Vol. 22, No. 1, pp.23-56.

Bilkey, W.J. and Tesar, G. (1977) 'The export behaviour of smaller-sized Wisconsin manufacturing firms', Journal of International Business Studies, Vol. 8, No. 1, pp.93-98.

Blesa, A., Ripollés, M. and Monferrer, D. (2007) 'Entrepreneurial and market orientations and international performance of Spanish and Belgian international new ventures', 36th EMAC Conference, 22-25 May, Reykjavik.

Blomstermo, A., Eriksson, K. and Sharma, D.D. (2004) 'Domestic activity and knowledge development in the internationalization process of firms', Journal of International Entrepreneurship, Vol. 2, pp.239-258.

Bloodgood, J.M., Sapienza, H.J. and Carsrud, A.L. (1995) 'The dynamics of new business star-ups: person, context and process', in Katz, J.A. and Brockhaus, R.H. (Eds.): Advances in Entrepreneurship, Firm Emergence and Growth, JAI Press, Greenwich, CT.

Boter, H. and Holmquist, C. (1996) 'Industry characteristics and internationalization processes in small firms', Journal of Business Venturing, Vol. 11, pp.471-487.

Brush, C. (1992) 'Factors motivating small firms to internationalize: the effects of firm age', Doctoral dissertation, Boston University, Boston, MA.

Burgel, O. and Murray, G.C. (2000) 'The international market entry choices of start-up companies in high-technology industries', Journal of International Marketing, Vol. 8, No. 2, pp.33-62.

Burpitt, W.J. and Rondinelli, D.A. (2000) 'Small firms' motivations for exporting: to earn and learn?', Journal of Small Business Management, Vol. 38, Vol. 4, pp.1-14.

Butler, J.E., Brown, B. and Chamornmarn, W. (2003) 'Informational networks, entrepreneurial action and performance', Asia Pacific Journal of Management, Vol. 20, pp.151-174.

Buzzell, R.D. and Gale, B.T. (1987) The PIMS principles. Linking strategy to performance, The Free Press, New York.

Buzzell, R.D. and Wiersema, F. (1981) 'Modeling changes in market share: a cross-sectional analysis', Harvard Business Review, Vol. 59, No. 1, pp.135-144.

Cadogan, J.W., Cui, C.C., Morgan, R.E. and Story, V.M. (2006) 'Factors facilitating and impeding the development of export market-oriented behavior: a study of Hong Kong manufacturing exporters', Industrial Marketing Management, Vol. 35, pp.634-647.

Cavusgil, T. (1980) 'On the internationalization process of firms', European Research, November, Vol. 8, pp.273-281.

Cavusgil, T. and Zou, S. (1994) 'Marketing strategy-performance relationship: an investigation of the empirical link in export market ventures', Journal of Marketing, Vol. 58, No. 1, pp.1-21.

Chakravarthy, B.S. (1982) 'Adaptation: a promising metaphor for strategic management', Academy of Management Review, Vol. 7, No. 1, pp.35-44.

Chen, H. (1999) 'International performance of multinationals: a hybrid model', Journal of World Business, Vol. 34, No. 2, pp.157-170.

Chetty, S. and Campbell-Hunt, C. (2004) 'A strategic approach on internationalization: a traditional versus a "born-global" approach', Journal of International Marketing, Vol. 12, No. 1, pp.57-81.

Christensen, C.H., Da Rocha, A. and Gertner, R.K. (1987) 'An empirical investigation of the factors influencing exporting success of Brazilian firms', Journal of International Business Studies, Vol. 18. No. 4, pp.61-77.

Cohen, M.D. and Levinthal, D.A. (1990) 'Absorptive capacity: a new perspective on learning and innovation', Administrative Science Quarterly, Vol. 35, No. 1, pp.128-152.

Collis, D.J. (1991) 'A resource-based analysis of global competition: the case of the bearings industry', Strategic Management Journal, Vol. 12, pp.49-68.

Cooper, R.G. and Kleinschmidt, E.J. (1985) 'The impact of export strategy on export sales performance', Journal of International Business Studies, Vol. 16, No. 1, pp.37-56. 
Coviello, N.E. (2006) 'The network dynamics of international new ventures', Journal of International Business Studies, Vol. 37, pp.713-731.

Coviello, N.E. and Jones, M.V. (2004) 'Methodological issues in international entrepreneurship research', Journal of Business Venturing, Vol. 19, No. 4, pp.485-508.

Coviello, N.E. and Martin, K.A. (1999) 'Internationalization of service SMEs: an integrated perspective from the engineering consulting sector', Journal of International Marketing, Vol. 7, No. 4, pp.42-66.

Coviello, N.E. and Munro, H.J. (1995) 'Growing the entrepreneurial firm networking for international market development', European Journal of Marketing, Vol. 29, No. 7, pp.49-61.

Coviello, N.E. and Munro, H.J. (1997) 'Network relationship and internationalisation process of the small software firms', International Business Review, Vol. 6, pp.361-386.

Crick, D. and Jones, M. (2000) 'Small high technology firms and international high technology markets', Journal of International Marketing, Vol. 8, No. 2, pp.63-85.

Crick, D. and Spence, M. (2005) 'The internationalization of 'high performing' UK high-tech SMEs: a study of planned and unplanned ventures', International Business Review, Vol. 14, No. 2, pp.167-85.

Dana, L.P. and Wright L.P. (2004) 'Emerging paradigms of international entrepreneurship', in Dana, L.P. (Ed.): Handbook of Research on International Entrepreneurship, Edward Elgar.

Davidsson, P. (2004) Researching on Entrepreneurship, Springer, New York, USA.

Day, G.S. (1994) 'The capabilities of market-driven organizations', Journal of Marketing, Vol. 58, No. 4, pp.37-52.

Deeds, D.L. and Hill, C.W.L. (1998) 'An examination of opportunistic action within research alliances: evidence from the biotechnology industry', Journal of Business Venturing, Vol. 11, No. 1, pp.41-56.

Diamantopoulos, A. (2003) 'Guest editorial', International Marketing Review, Vol. 20, No. 1, pp.13-13.

Diamantopoulos, A. and Winklhofer, H. (2001) 'Index construction with formative indicators: an alternative to scale development', Journal of Marketing Research, Vol. 38, No. 2, pp.269-277.

Dimitratos, P. and Jones, M.V. (2005) 'Future directions for international entrepreneurship research', International Business Review, Vol. 14, No. 2, pp.119-131.

Douglas, S.P. and Craig, C.S. (1989) 'Evolution of global marketing strategy: scale, scope and synergy', Columbia Journal of World Business, Fall, pp.47-58.

Douglas, S.P. and Wind, Y. (1987) 'The myth of globalization', Columbia Journal of World Business, Winter, pp.19-29.

Dunning, J.H. (1988) Explaining International Production, Unwin Hyman, London.

Eisenhardt, K.M. and Martin, J.A. (2000) 'Dynamic capabilities: what are they?', Strategic Management Journal, Vol. 21, Nos. 10/11, pp.1105-1121.

Elg, U. (2002) 'Inter-firm market orientation: its significance and antecedents in distribution networks', Journal of Marketing Management, Vol. 18, Nos. 7/8, pp.633-656.

Elg, U. (2008) 'Inter-firm market orientation and the influence of network and relational factors', Scandinavian Journal of Management, Vol. 24, pp.55-68.

Ellis, P. and Pecotich, A. (2001) 'Social factors influencing export initiation in small and medium-sized enterprises', Journal of Marketing Research, Vol. 38 No. 1, pp.119-130.

Eriksson, K. and Chetty, S. (2003) 'The effect of experience and absorptive capacity on foreign market knowledge', International Business Review, Vol. 12, pp.673-695.

Eriksson, K., Johanson, J., Majkgard, A. and Sharma, D. (1997) 'Experiential knowledge and cost in the internationalization process', Journal of International Business Studies, Vol. 28, pp.237-260. 
Fernhaber, S.A. and McDougall, P. (2005) 'New ventures growth in international markets: the role of strategic adaptation and networking capabilities', in Shepherd D.A. and Katz J.A. (Eds.): International Entrepreneurship, pp.111-135, Elsevier, UK.

Gabrielsson, M., Kirpalani, V.H.M., Dimitratos, P., Solberg, C.A. and Zucchella, A. (2008) 'Born globals: propositions to help advance the theory', International Business Review, Vol. 17, No. 4, pp.385-401.

Gleason, K., Payne, B. and Wiggenhorn, J. (2007) 'An empirical investigation of going private decisions of U.S. firms', Journal of Economics and Finance, Vol. 31, No. 2, pp.207-218.

Godesiabois, J. (2005) 'Network analysis in an international entrepreneurial environment', Advances in Entrepreneurship, Firm Emergence and Growth, Vol. 8, pp.137-164.

Greenley, G.E., Hooley, G.J., Broderick, A.J. and Rudd, J.M. (2004) 'Strategic planning differences among different multiple stakeholder orientation profiles', Journal of Strategic Marketing, Vol. 12, No. 3, pp.163-82.

Greiner, L.E. (1972) 'Evolution and revolution as organisations grow', Harvard Business Review, Vol. 4, pp.37-46.

Hair, J.F. Jr., Anderson, R.E., Tatham, R.L. and Black, W.C. (1999) Análisis Multivariante, Prentice Hall, Madrid.

Hambrick, D.C. (1981) 'Strategic awareness within top management team', Strategic Management Journal, Vol. 2, No. 3, pp.263-279.

Hashai, N. and Almor, T. (2004) 'Gradually internationalizing born global firms - an oxymoron?', International Business Review, Vol. 13, No. 4, pp.465-483.

Hessels, J. and van Stel, A. (2009) 'Export-driven new ventures and economic growth', Center for Economic Institutions Working Paper Series, pp.2008-2023.

Hildebrant, L. (1987) 'Consumer retail satisfaction in rural areas: a reanalysis of survey data', Journal of Economic Psychology, Vol. 8, pp.19-42.

Hill, J.S. and Still, R.R. (1984) 'Adapting products to LDC tastes', Harvard Business Review, Vol. 62, No. 2, pp.92-101.

Hitt, M.A., Hoskisson, R.E. and Kim, H. (1997) 'International diversification: effects on innovation and firm performance in product-diversified firms', Academy of Management Journal, Vol. 40, No. 4, pp.767-798.

Hogarth, R.M. and Makridakis, S. (1981) 'Forecasting and planning: an evaluation', Management Science, Vol. 27, No. 2, pp.115-138.

Hooley, G., Greenley, G. and Fahy, J. (2002) 'A scale for measuring marketing capabilities', in Farhangmehr, M. (Ed.): Marketing in a Changing World: Scope, Opportunities and Challenges, Proceedings (CD) of the 31st EMAC Conference, 28-31 May 2002, Braga, Portugal.

Hooley, G.J., Lynch, J.E. and Jobber, D. (1992) 'Generic marketing strategies', International Journal of Research in Marketing, Vol. 9, pp.75-89.

Hou, J. (2008) 'Toward a research model of market orientation and dynamic capabilities', Social Behavior and Personality, Vol. 36, No. 9, pp.1251-1268.

Hurmerinta-Peltomaki, L. (2002) 'Time and studies on rapid internationalisation', Proceedings (CD) of the 31st EMAC Conference, 28-31 May 2002, Braga, Portugal.

Jantunen, A., Puumalainen, K., Saarenketo, S. and Kyläheiko, K. (2005) 'Entrepreneurial orientation, dynamic capabilities and international performance', Journal of International Entrepreneurship, Vol. 3, No. 3, pp.223-243.

Jarvis, C.B, Mackenzie, S.B. and Podsakoff, P.M. (2003) 'A critical review of construct indicators and measurement model misspecification in marketing and consumer research', Journal of Consumer Research, Vol. 30, No. 2, pp.199-218.

Johanson, J. and Vahlne, J.E. (1977) 'The internationalization process of the firm: a model of knowledge development and increasing foreign market commitment', Journal of International Business Studies, Vol. 8, No. 1, pp.23-32. 
Johanson, J. and Vahlne, J.E. (1990) 'The mechanism of internationalization', International Marketing Review, Vol. 7, No. 4, pp.11-24.

Johanson, J. and Wiedersheim-Paul, F. (1975) 'The internationalization of the firm: four Swedish cases', Journal of Management Studies, Vol. 12, pp.305-322.

Johnson, J.E. (2004) 'Factors Influencing the early internationalization of high technology startups: US and UK evidence', Journal of International Entrepreneurship, Vol. 2, pp.139-154.

Jolly, V.K., Alahunta, M. and Jeannet, J.P. (1992) 'Challenging the incumbents: how high technology start-ups compete globally', Journal of Strategic Change, Vol. 1, pp.71-82.

Jöreskog, K. and Sörbom, D. (1993) LISREL 8: Structural Equation Modeling with the SIMPLIS Command Language, Scientific Software International, Chicago, Illinois.

Katsikeas, C.S., Piercy, N.F. and Loannidis, C. (1996) 'Determinants of export performance in a European context', European Journal of Marketing, Vol. 30, No. 6, pp.6-35.

Keeble, D., Lawson, C., Lawton Smith, H., Moore, B. and Wilkinson, F. (1996) 'Internationalisation processes and networking in technology-intensive small firms', in Institute of Small Business Affairs (Ed.): Enterprising Futures conference proceedings, UCE Business School, Birmingham.

Killough, J. (1978) 'Improved payoff from transnational advertising', Harvard Business Review, July-August, pp.102-110.

Kim, W.C. and Hwang, P. (1992) 'Global strategy and multinationals' entry mode choice', Journal of International Business Studies, Vol. 23, No. 1, pp.29-53.

Kleinbaum, D.G., Kupper, L. and Muller, K.E. (1988) Applied Regression Analysis and Other Multivariable Methods, PWS-Kent, Boston.

Kogut, B. (1985) 'Designing global strategies: profiting from operational flexibility', Sloan Management Review, Vol. 27, No. 1, pp.27-38.

Kotha, S. and Vadlami, B.L. (1995) 'Assessing generic strategies: an empirical investigation of competing typologies in discrete manufacturing industries', Strategic Management Journal, Vol. 16, No. 1, pp.75-83.

Kuivalainen, O., Sundqvist, S. and Servais, P. (2007) 'Firms' degree of born-globalness, international entrepreneurial orientation and export performance', Journal of World Business, Vol. 42, No. 3, pp.253-267.

Laanti, R., Gabrielsson, M. and Gabrielsson, P. (2007) 'The globalization strategies of business-tobusiness born global firms in the wireless technology industry', Industrial Marketing Management, Vol. 36, No. 8, pp.1104-1117.

Leonidou, L. (2004) 'An analysis of the barriers hindering small business export development', Journal of Small Business Management, Vol. 42, No. 3, pp.279-302.

Leonidou, L.C., Katsikeas, C.S. and Samiee, S. (2002) 'Marketing strategy determinants of export performance: a meta-analysis', Journal of Business Research, Vol. 55, No. 1, pp.51-68.

Lim, J.S., Sharkey, T.W. and Kim, K.I. (1993) 'Determinants of international marketing strategy', Management International Review, Vol. 33, No. 2, pp.103-120.

Loane, S. and Bell, J. (2006) 'Rapid internationalisation among entrepreneurial firms in Australia, Canada, Ireland and New Zealand', International Marketing Review, Vol. 23, No. 5, p.467.

Madsen, T.K. and Servais, P. (1997) 'The internationalization of born globals: an evolutionary process?', International Business Review, Vol. 7, pp.561-583.

Madsen, T.K., Rasmussen, E.S. and Servais, P. (2000) 'Differences and similarities between bom globals and other types of exporters', in Yaprak, A. and Tutek, J. (Eds.): Globalization, the Multinational Firm and Emerging Economies, Advances in International Marketing, Vol. 10, pp.247-265, JAIlElsevier Inc., Amsterdam.

Manu, F.A. (1992) 'Innovation orientation, environment and performance: a comparison of U.S. and European markets', Journal of International Business Studies, Vol. 23, No. 2, pp.333-359. 
Mazaira, A., Dopico, A. and González, E. (2005) 'Incidencia en el grado de orientación al mercado de las organizaciones empresariales en el desarrollo de las capacidades estratégicas de marketing', Revista Europea de Dirección y Economía de la Empresa, Vol. 14, No. 3, pp.181-208.

McDougall, P.P. and Oviatt, B.M. (1996) 'New venture internationalization, strategic change, and performance: a follow-up study', Journal of Business Venturing, Vol. 11, No. 1, pp.23-40.

McDougall, P.P. and Oviatt, B.M. (2000) 'International entrepreneurship: the intersection of two research paths', Academy of Management Journal, Vol. 43, No. 5, pp.902-906.

McDougall, P.P., Shane, S. and Oviatt, B.M. (1994) 'Explaining the formation of international new ventures: the limits of theories from international business research', Journal of Business Venturing, Vol. 9, pp.469-487.

Miles, R.E. and Snow, C.C. (1978) Organizational Strategy, Structure and Process, McGraw-Hill, New York.

Miles, R.E., Snow, C.C. and Pfeffer, J. (1974) 'Organization-environment: concepts and issues', Industrial Relations, Vol. 13, pp.244-264.

Miller, D. and Toulouse, J. (1986) 'Chief executive personality and corporate strategy and structure', Management Science, Vol. 32, pp.1389-1409.

Morgan, N.A., Vorhies, D.W. and Schlegelmich, B.B. (2006) 'Resource-performance relationships in industrial export ventures: the role of resource inimitability and substitutability', International Marketing Management, Vol. 35, pp.621-633.

Newbert, S.L. (2005) 'New firm formation: a dynamic capability perspective', Journal of Small Business Management, Vol. 43, No. 1, pp.55-77.

Newbert, S.L. (2007) 'Empirical research on the resource-based view of the firm: an assessment and suggestions for future research', Strategic Management Journal, Vol. 28, pp.121-146.

Nunnaly, J. (1979) Psychometric Theory, McGraw-Hill, New York.

O'Driscoll, A., Carson, D. and Gilmore, A. (2000) 'Developing marketing competence and managing in networks: a strategic approach', Journal of Strategic Marketing, Vol. 8, No. 2, pp.183-196.

OECD (1997) Globalisation and Small and Medium Enterprises (SMEs), OECD, Paris.

Ongkittikul, S. and Geerlings, H. (2006) 'Opportunities for innovation in public transport: effects reforms on innovative capabilities', Transport Policy, Vol. 13, pp.283-293.

Oviatt, B.M. and McDougall, P.P. (1994) 'Toward a theory of international new ventures', Journal of International Business Studies, First Quarter, pp.45-64.

Oviatt, B.M. and McDougall, P.P. (2005) 'Defining international entrepreneurship and modelling the speed of internationalization', Entrepreneurship: Theory and Practice, Vol. 29, No. 5, pp.537-553.

Pettus, M.L., Kor, Y.Y. and Mahoney, J.T. (2007) 'A theory of change in turbulent environments: the sequencing of dynamic capabilities following industry deregulation', Working papers.

Porter, M.E. (1986) 'Changing patterns of international competition', California Management Review, Vol. 28, No. 2, pp.9-40.

Reid, S.D. (1981) 'The decision-maker and export entry and expansion', Journal of International Business Studies, Vol. 12, No. 4, pp.101-112.

Rialp, A., Rialp, J. and Knight, G.A. (2005) 'The phenomenon of early internationalizing firms: what do we know after a decade (1993-2003) of scientific inquiry?', International Business Review, Vol. 14, No. 2, pp.147-166.

Rindova, V.P. and Kotha, S. (2001) 'Continuous 'morphing': competing through dynamic capabilities, form, and function', Academy of Management, Vol. 44, No. 6, pp.1263-1280.

Sapienza, H.J., De Clercq, D. and Sandberg, W.R. (2005) 'Antecedents of international and domestic learning effort', Journal of Business Venturing, Vol. 20, No. 4, pp.437-457. 
Schreyo, G. and Kliesch-Eberl, M. (2007) 'How dynamic can organizational capabilities be? Towards a dual-process model of capability dynamisation', Strategic Management Journal, Vol. 28, pp.913-933.

Shan, W. and Song, J. (1997) 'Foreign direct investment and the sourcing of technological advantage: evidence from the biotechnology industry', Journal of International Business Studies, Vol. 28, No. 2, pp.267-284.

Shane, S. (2003) 'A General Theory of Entrepreneurship: The Individual-Opportunity Nexus', New Horizons in Entrepreneurship, Edward Elgar, Cheltenham.

Shoham, A. (1998) 'Export performance: a conceptualisation and empirical assessment', Journal of International Marketing, Vol. 6, No. 3, pp.59-81.

Slater, S.F. and Narver, J.C. (1994) 'Does competitive environment moderate the market orientation-performance relationship?', Journal of Marketing, Vol. 58, No. 1, pp.46-55.

Slater, S.F. and Narver, J.C. (1995) 'Market orientation and the learning organization', Journal of Marketing, Vol. 59, No. 3, pp.63-74.

Steenkamp, J.M. and Van Trijp, H.C.M. (1991) 'The use of LISREL in validating marketing constructs', International Journal of Research in Marketing, Vol. 8, No. 4, pp.283-299.

Stopford, J.M. and Wells, L.T. Jr. (1972) Managing the Multinational Enterprise, Basic Book, New York.

Styles, C. (1998) 'Export performance measures in Australia and the United Kigdom', Journal of International Marketing, Vol. 6, No. 3, pp.12-36.

Teece, D.J. (2007) 'Explicating dynamic capabilities: the nature and microfoundations of (sustainable) enterprise performance', Strategic Management Journal, Vol. 28, pp.1319-1350.

Teece, D.J., Pisano, G. and Shuen, A. (1997) 'Dynamic capabilities and strategic management', Strategic Management Journal, Vol. 18, No. 7, pp.509-533.

Theodosiou, M. and Leonidou, L.C. (2003) 'Standardization versus adaptation of international marketing strategy: an integrative assessment of the empirical research', International Business Review, Vol. 12, pp.141-171.

Trulsson, P. (2002) 'Constraints of growth oriented enterprises in the southern and eastern African region', Journal of Developmental Entrepreneurship, Vol. 7, No. 3, pp.331-339.

Vorhies, D.W. and Morgan, N.A. (2005) 'Benchmarking marketing capabilities for sustainable competitive advantage', Journal of Marketing, Vol. 69, pp.80-94.

Vyas, R. and Souchon, A. (2003) 'Symbolic use of export information, a multidisciplinary approach to conceptual development and key consequences', International Marketing Review, Vol. 20, No. 1, pp.67-94.

Wagner, H. (2004) 'Internationalization speed and cost efficiency: evidence from Germany', International Business Review, Vol. 13, pp.447-463.

Walters, P.G.P. and Toyne, B. (1989) 'Product modification and standardization in international markets: strategic options and facilitating policies', Columbia Journal of World Business, Winter, pp.37-44.

Wang, C.L. and Ahmed, P.K. (2007) 'Dynamic capabilities: a review and research agenda', International Journal of Management Reviews, Vol. 9, No. 1, pp.31-51.

Weerawardena, J, Sullivan, G., Liesch, P.W. and Knight, G. (2007) 'Conceptualizing accelerated internationalization in the born global firm: a dynamic capabilities perspective', Journal of World Business, Vol. 42, pp.294-306.

Weerawardena, J. (2003) 'The role of marketing capability in innovation-based competitive strategy', Journal of Strategic Marketing, Vol. 11, pp.15-35.

Wu, L. (2009) 'Applicability of the resource-based and dynamic-capability views under environmental volatility', Journal of Business Research, in press.

Wu, L.Y. (2006) 'Resource, social capital, path dependence and dynamic capability', Management Review, Vol. 25, No. 1, pp.121-140. 
Yeoh, P. (2004) 'International learning: antecedents and performance implications among newly internationalizing companies in an exporting context', International Marketing Review, Vol. 21, Nos. 4/5, pp.511-535.

Zaheer, S. (1995) 'Overcoming the liability of foreignness', Academy of Management Journal, Vol. 38, pp.341-363.

Zahra, S.A. (2005) 'A theory of international new ventures: a decade of research', Journal of International Business Studies, Vol. 36, No. 1, pp.20-28.

Zahra, S.A. and George, G. (2002) 'International entrepreneurship: the current status of the field and future research agenda', in Hitt, M.A., Ireland, R.D., Camp, S.M. and Sexton, D.L. (Eds.): Strategic Entrepreneurship: Creating a New Mindset, pp.255-288, Blackwell Publishers, Oxford, UK.

Zahra, S.A., Ireland, R.D. and Hitt, M.A. (2000) 'International expansion by new venture firms: international diversity, mode of market entry, technological learning, and performance', Academy of Management Journal, Vol. 43, No. 5, pp.925-950.

Zahra, S.A., Sapienza, H.J. and Davidsson, P. (2006) 'Entrepreneurship and dynamic capabilities: a review, model and research agenda', Journal of Management Studies, Vol. 43, No. 4, pp.917-955.

Zain, M. and Imm, S. (2006) 'The impacts of network relationships on SMEs' internationalization process', Thunderbird International Business Review, Vol. 48, No. 2, pp.183-205.

Zheng, C. and Kavul, S. (2005) 'Capability development, learning and growth in international entrepreneurial fFirms: evidence from China', in Shepherd, D.A. and Katz, J.A. (Eds.): International Entrepreneurship, pp.273-296, Elsevier, UK.

Zhou, K.Z. and Li, C. (2009) 'How strategic orientations influence the building of dynamic capability in emerging economies', Journal of Business Research, in press.

Zollo, M. and Winter, S.G. (2002) 'Deliberate learning and the evolution of dynamic capabilities', Organization Science, Vol. 13, pp.339-351.

Zucchella, A., Palamara, G. and Denicolai, S. (2007) 'The drivers of the early internationalization of the firm', Journal of World Business, Vol. 3, pp.268-280. 